\title{
GOTLAND: THE ANATOMY OF A SILURIAN T CARBONATE PLATFORM \\ by
}

Sven Laufeld and Michael G. Bassett

The geology of Gotland is particularly well known for its rich fossil assemblages and its reefs and other carbonate buildups. The succession as a whole presents a remarkably full picture of a pulsatory regression across a Silurian carbonate platform. This article highlights some features of Gotland's geology as background information for participants in the plenary meeting of IGCP's Project Ecostratigraphy in August*, and as an introduction for the many other geologists who visit the Swedish island each year.

The discovery of fossils in Stone Age graves on Gotland provides evidence of man's awareness since prehistoric times of the impressive geological features of this island in the Baltic Sea. Such an awareness is hardly surprising given the extensive exposure along the sea-cliffs in particular. Yet it was not until 1717 that any of the features entered the literature when Emanuel Swedenborg illustrated in his Daedalus Hyperboreus a trilobite and a brachiopod that fairly certainly originated from Gotland.
The most notable visitor in the 18 th century was Linnaeus who made his only tour of the island in 1741 and when, apart from botanical specimens, he collected mainly fossil corals along with a few examples of other groups. He was later to include material from these collections in his definitive nomenclatorial publication Systema Naturae. In his travel account of Gotland, Linnaeus also noted other topographical and geological features and correctly interpreted the mode of origin of an area of limestone sea-stacks (Swedish rauk,

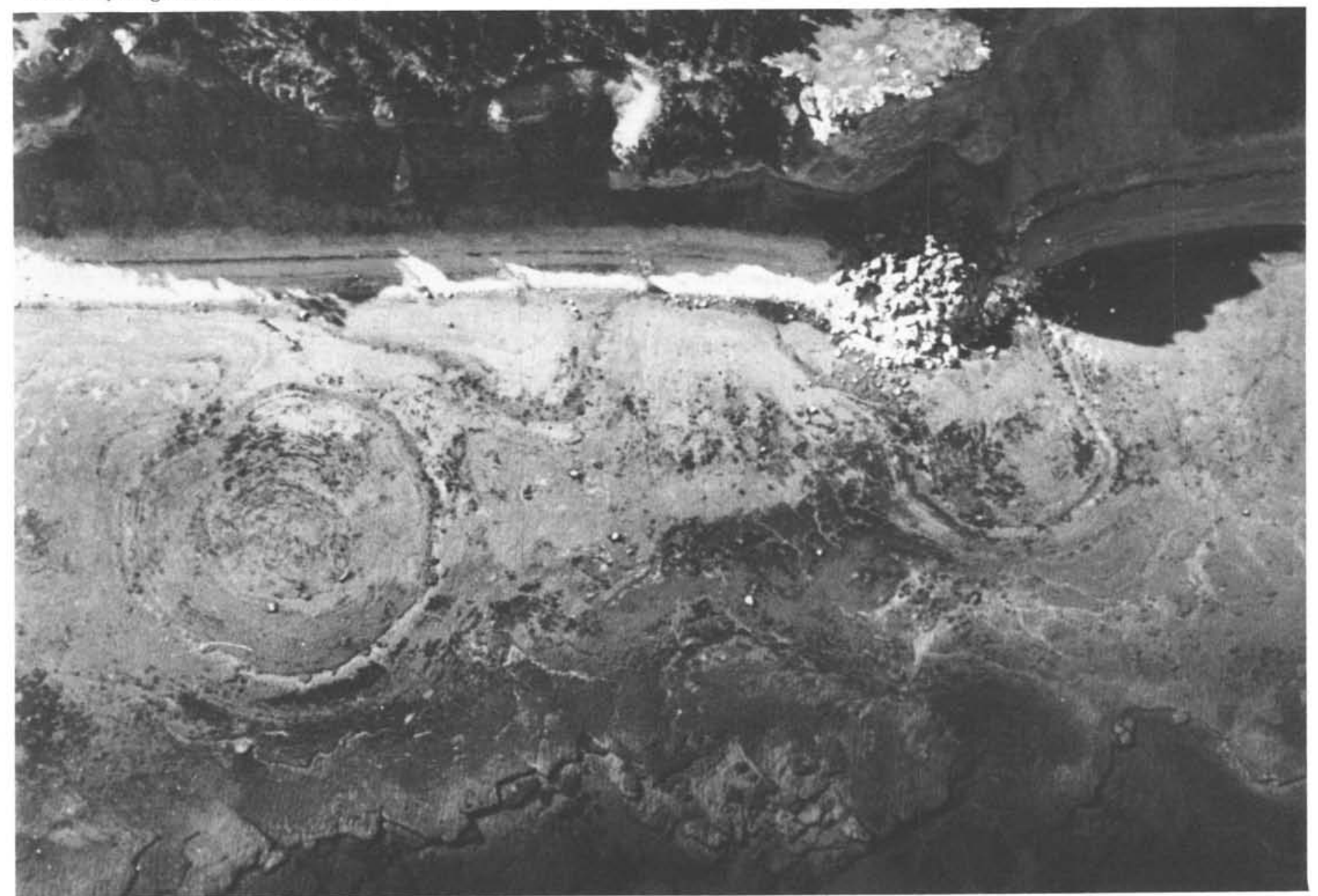

Low level aerial view of the remnants of early Wenlock (Silurian) reefs preserved in the Högklint Beds SW of Lickershamn, NW coast of the island of Gotland, Sweden. The circular structures (known as Philip structures) in the submarine wave-cut platform in front of the cliffs were formed by the sagging of reefs into underlying Lower Visby sediments. Numerous similar structures along this coast have been used to map the former distribution of reefs that have been eroded away during the last 6000 years. (Photo courtesy A. Philip; all aerial photographs in this article have been approved for publication by the Swedish Defence Staff.)

\footnotetext{
* IGCP Project 53 (Ecostratigraphy) will hold its Plenary Discussion and Field Meeting from August 22 to 28 on the island of Gotland. The meeting will be based at Allekvia, former court house for the northern half of the island, but now a geological field station run by the Swedish Project Working Group for Ecostratigraphy and financed by the Swedish Natural Science Research Council (NFR).
} 
Topographically, Gotland can be divided into five broad zones coincident with and controlled by the main rock types (Fig. 2). In the north, central, and southern areas there are extensive tracts of limestone trending approximately parallel to the strike and forming the higher land at an elevation of $30-80 \mathrm{~m}$; these limestone areas terminate in the vertical and near-vertical cliffs (Swedish klint) that form the most spectacular features of Gotland's scenery. Between the limestone areas are two lower zones $(<35 \mathrm{~m})$ in which the main rock types are a variety of calcareous shales, mudstones, and highly argillaceous limestones generally described together as marlstones; the southern marlstone area has sandstones and oolitic limestones developed along its southern boundary.

The exposed Silurian sequence is about $500 \mathrm{~m}$ thick, while boreholes and geophysical studies show that the island is underlain by older Silurian (approx. $150 \mathrm{~m}$ ), Ordovician (75$125 \mathrm{~m})$, and Cambrian-Precambrian (150-225 m) sediments resting on a Precambrian crystalline basement, the surface of which dips very gently to the south. Younger Silurian strata (for example 'Graptolithenkalk', 'Beyrichienkalk') crop out on the floor of the Baltic south of Gotland. All these Palaeozoic sediments were deposited in the shallow Balto-Scandian basin situated on the Precambrian Shield area toward the western margin of the Russian Platform. To the west of the Shield lay the oceanic trough that was to become the collision zone along which the Scandinavian Caledonides were formed.

\section{Stratigraphy and Facies}

Hede established a subdivision of the Gotland Silurian sequence into thirteen primary mappable units, based largely on lithological characteristics, but also in part on diagnostic fossil assemblages. In that sense they are essentially combined units of the type referred to increasingly as topostratigraphical. Within these divisions he recognized more than fifty subunits that represent both lateral facies associations and a vertically successive stratigraphy. The thicknesses of the units and subunits vary considerably along the strike; figures given below are maximum thicknesses.

Lower Visby Beds $(9 \mathrm{~m}+)$. The oldest exposed strata are soft calcareous mudstones and thin argillaceous limestones that crop out intermittently along the NW shore. Soft-bottom faunas are dominant, with some low, intervening banks formed mainly of halysitid corals and pentamerid brachiopods.

Upper Visby Beds $(15 \mathrm{~m})$. Irregularly bedded to nodular argillaceous limestones, with shale and mudstone intercalations, grade upward from the underlying unit. The lithological transition is accompanied by a distinct faunal change that correlates closely with the Llandovery-Wenlock Series boundary. Limestones become thicker and more regularly bedded upward, accompanied by an increase in hard-bottom faunas; small, unstratified carbonate mounds first appear at this level. As at many horizons in the Gotland sequence, there are a number of prominent bentonites in the Upper Visby Beds.

Högklint Beds $(35 \mathrm{~m})$. Massive reefs containing a wealth of organic remains dominate this part of the lower Wenlock sequence. Inter-reef beds comprise highly crinoidal bedded limestones grading into thinner, more argillaceous limestones and marlstones. The beds are conglomeratic in places and rippled, and there is evidence at the top of extreme shallowing and local emersion.

Tofta Beds $(3 \mathrm{~m})$. An apparent hiatus at both the base and top of the Tofta Beds is evident at some localities as a slight angular discordance. Thick lenses of stromatoporoids, algal oncolites, and oolites are interbedded with fine argillaceous limestones in which fossils are generally rare. There is again evidence of local emersion.

Stite Beds $(100 \mathrm{~m})$. The complex of facies developed in middle Wenlock times incorporates several successive generations of reefs and mounds in the NE outcrop areas. Bedded limestones, often rich in crinoidal and bryozoan debris, pass EPISODES, Vol. 1981, No. 2.

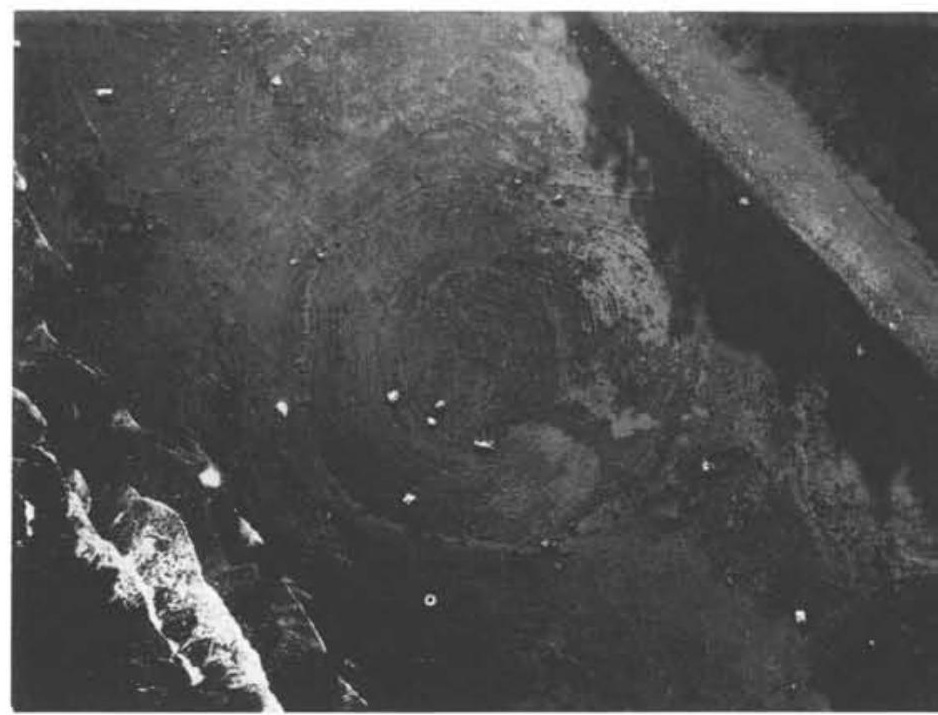

Figure 4. Aerial view of the submarine wave-cut platform at Balsklint, west of Lickershamn, NW coast of Gotland. The circular Philip structure is developed in the Lower Visby Beds and was caused by the sagging of a Högklint reef into underlying sediments. (Photo courtesy A. Philip)

gradually south-westward into more argillaceous sediments. The highest $5 \mathrm{~m}$ of Slite Beds in the SW comprise a distinctive unit of siliciclastic rippled sediments known as the Slite Siltstone.

Halla Beds $(15 \mathrm{~m})$. Coarse, almost white, oolitic limestones enclosing small unstratified mounds rest disconformably in places on the Slite Beds. The bedded oolites pass up into bituminous and argillaceous limestones with numerous small patch reefs; rippled horizons are well developed. The Halla Beds thin out south-westward on the main island but reappear on the Karlsö islands off the west coast as porcelaneous limestones.

Mulde Beds (25m). Extremely fossiliferous marlstones and interbedded argillaceous limestones forming the bulk of the Mulde Beds are generally similar in facies to the lower parts of the Visby Beds. The limestones become more dominant as this unit thins out to the NE.

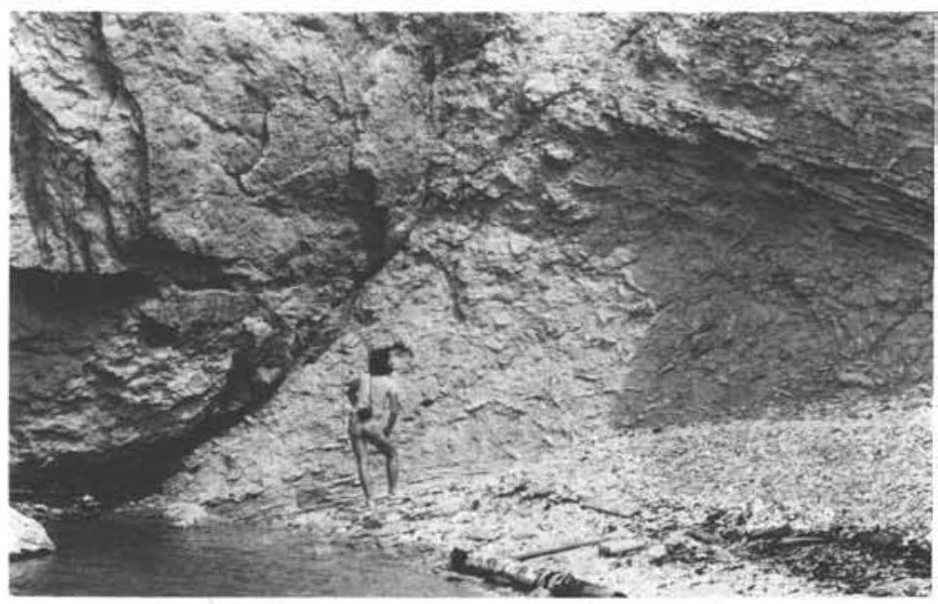

Figure 5. Lilla Karlsö island, off the west coast of southcentral Gotland. Limestone breccia in Slite Beds formed by a penecontemporaneous slide of reefal limestones into adjacent upper Slite sediments. The slide was probably triggered by tectonic movements in nearby areas.

Klinteberg Beds $(70 \mathrm{~m})$. SW exposures largely comprise reefs dominated by stromatoporoids and massive tabulate corals, with thick-bedded, coarsely crinoidal inter-reef limestones. To the NE, the reef tract passes laterally into a complex facies mosaic of bedded limestones containing abundant 
oncolitic algae; some argillaceous limestone units contain low banks of thick-shelled bivalves. The boundary between the Wenlock and Ludlow Series appears to lie within the Klinteberg Beds.

Hemse Beds $(100 \mathrm{~m})$. Sedimentation patterns through early to middle Ludlow times were similar to those in the Slite Beds. The limestone areas to the NE incorporate a number of spectacular mounds formed largely of stromatoporoids, and banks of bivalves are common; the SW marlstones have yielded the most common graptolites in the Gotland sequence. There are a number of prominent hardground surfaces in the top of these beds and in the overlying strata, and many of the limestones are rippled (Fig. 6).

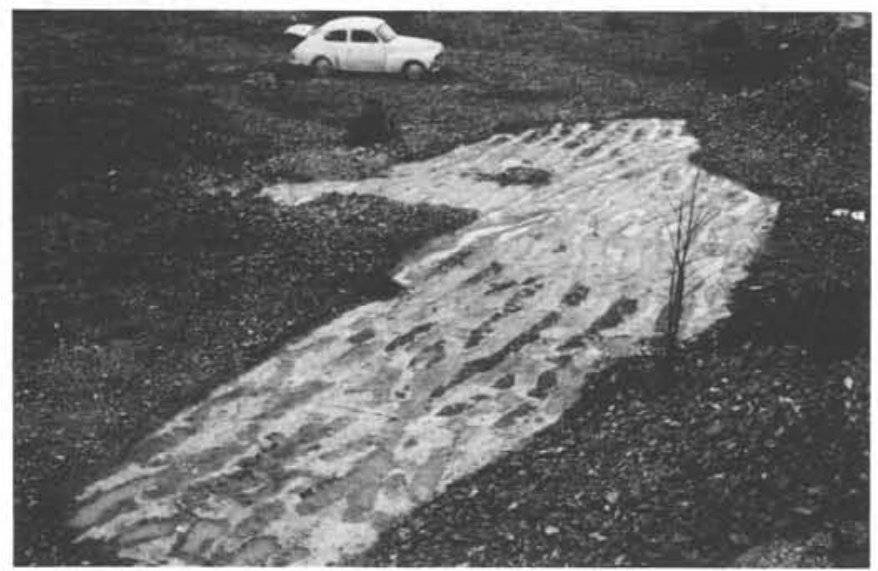

Figure 6. Part of an extensive rippled limestone surface in the Hemse Beds, Gannes, Gotland. (Photo courtesy B. Sundquist)

Eke Beds $(15 \mathrm{~m})$. The base of the Eke Beds is marked by a fairly sharp increase in the percentage of calcareous algae, which are common throughout the argillaceous limestones and micaceous marlstones forming much of this unit. Small reefs and mounds are present in the NE outliers, where there is evidence of local emersion.

Burgsvik Beds $(50 \mathrm{~m})$. Thick Silurian sandstones were first deposited in the Gotland area early in late Ludlow times. The sediments are fine grained, mainly thickly bedded, calcareous to argillaceous sands with thinly bedded intercalations of shales and marlstones. In places the sandstones are overlain by thinly bedded oolitic limestones or by interbeds of oolites, sands, and marls. Macrofossils are generally rare, but spores from these beds are proving to be important in the current debate on the origin of vascular land plants. Penecontemporaneous plastic deformation and water escape structures are particularly well preserved at some localities in the Burgsvik sandstones (Fig. 7), which thin out fairly rapidly both to the NE and SW.

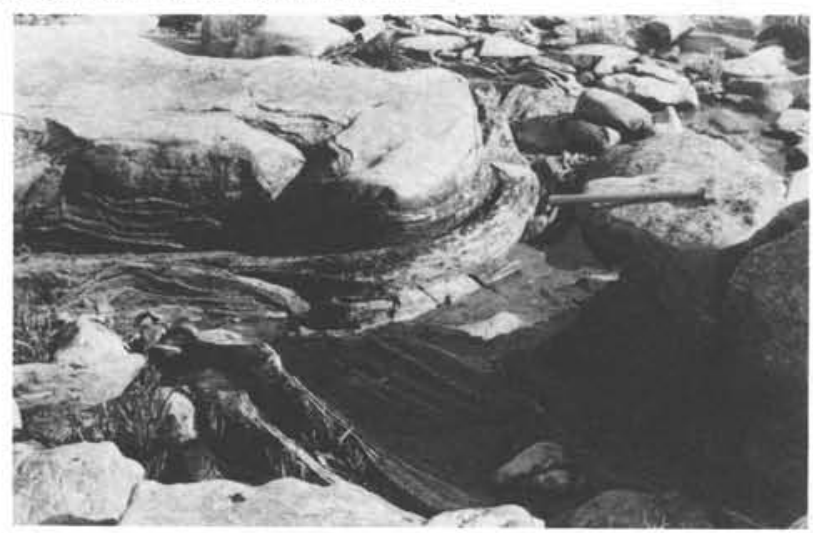

Figure 7. 'Megaloadcasts' in the Burgsvik Beds south of Burgsvik. Tectonically triggered shocks caused parts of the semi-indurated sand beds to sag into the underlying shaly sediment that then became plastically deformed and curled up around the sand bodies.

EPISODES, Vol. 1981, No. 2.
Hamra Beds $(40 \mathrm{~m})$. Poorly stratified algal limestones form the base of this unit, passing up into argillaceous limestones and then reefal and detrital crinoidal beds. The beds thin toward outliers in the NW, where small stromatoporoid mounds are common.

Sundre Beds $(10 \mathrm{~m})$. The youngest beds exposed on Gotland contain faunas indicative of a late Ludlow age. Variegated coloured limestones include thick beds of crinoidal debris and stromatoporoid and algal dominated reefs. The Sundre Beds form the distinctive rauk fields on the southernmost and SE coast of the island (Fig. 8). Infillings of sediment in fissures within the highest beds also contain Ludlow faunas, and the first evidence of post-Ludlow strata is found in argillaceous limestone boulders from the Hoburg Bank, some $30 \mathrm{~km}$ to the south in the Baltic.

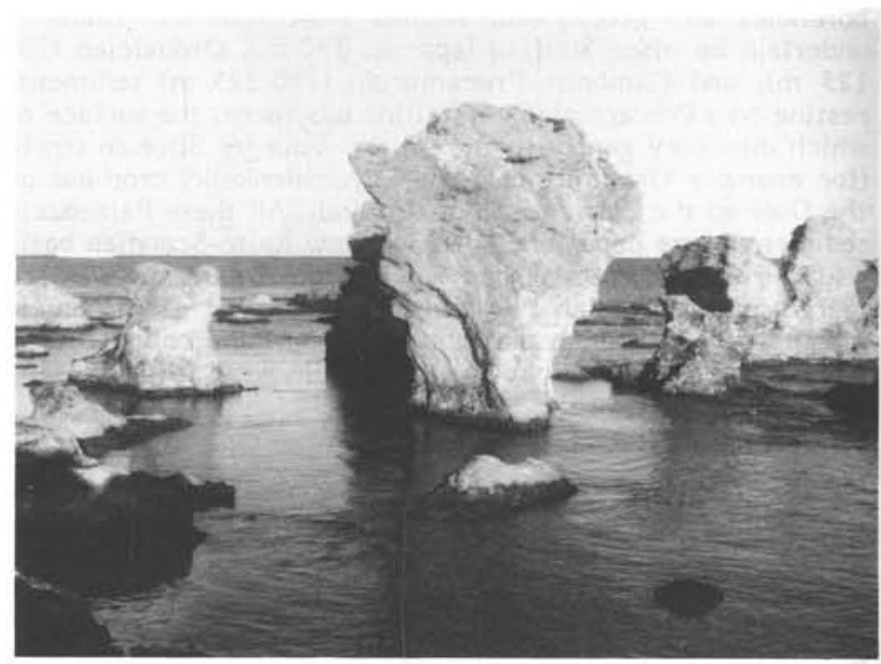

Figure 8. Sea-stacks (raukar) cut in limestones of the Sundre Beds, Holmhällar, southernmost Gotland.

\section{Environmental and Palaeogeographical Synthesis}

The early Silurian sea that transgressed across the Baltic area had a shoreline considerably to the north of Gotland, as the Llandovery facies in the island's subsurface comprise mostly fine-grained, offshore argillaceous sediments, including dark graptolitic mudstones. Nowhere in the Palaeozoic of the Balto-Scandian basin is there evidence of sediment instability associated with submarine slopes; instead, the picture is of deposition on a gently dipping platform at no great depth, with the different major lithofacies mainly reflecting relative water energy and relative distance from source areas. Any shallow-water Silurian sediments deposited to the north of Gotland have been removed by subsequent erosion, but the Lower Visby to Upper Visby sequence indicates an increase in water energy and gradual shallowing close to the present northern coast at the end of Llandovery times.

From then until the end of the Ludlow Epoch, deposition in the Gotland area was dominated by carbonate sedimentation and the formation of reefs, indicative of a shallow, epicontinental sea environment at low latitudes. The presence of algae throughout the sequence indicates that deposition was entirely within the photic zone, and probably at less than 100 $\mathrm{m}$. Progressively lower energy, offshore environments lay consistently to the south and SW of the reef tracts, reflected in the fact that limestone units at any one level pass laterally in those directions into more argillaceous sediments. The growth of successive generations of reefs took place progressively south-eastward, as seen today in the successive Gotland stratigraphical units; this can be interpreted as part of a gradual migration of all the facial belts to the SE with time. Interruption of reef deposition from time to time appears to represent periods of minor pulsatory transgressions imposed on the overall regressive cycles.

The lateral and vertical successions of facies throughout Gotland thus present a classical example of Walther's Law: 
since there was a consistent pattern of migrating, subparallel sedimentation belts in front of the reef tracts, it follows that the lithological units recognized in the stratigraphical scheme described above must be diachronous in detail, and that parts of some of the different units must be laterally coeval. Relationships of this kind are particularly complex in the interval covering the upper Slite, Halla, Mulde, Klinteberg, and lower Hemse Beds, which appear at some levels to represent lateral facies of a synchronous belt.

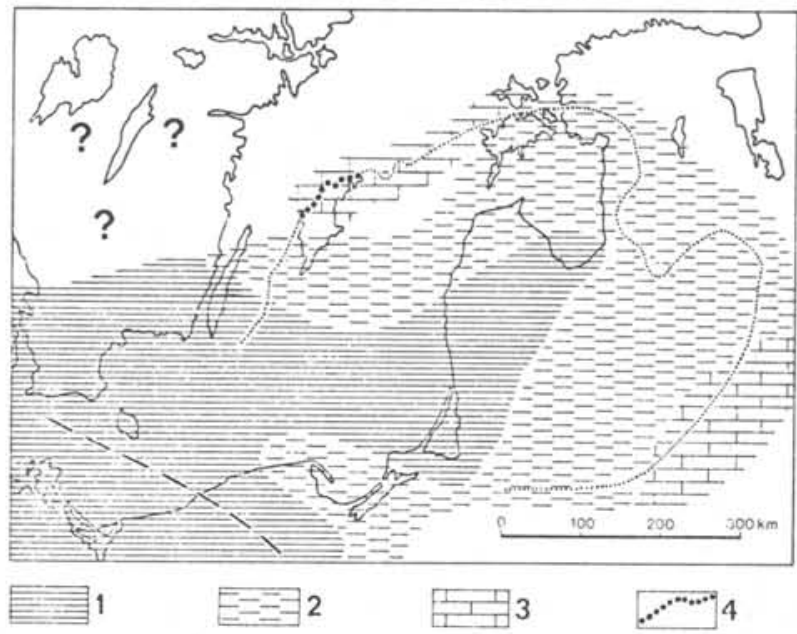

Figure 9. General distribution of main lithofacies in southern Balto-Scandia in early Wenlock times, equating with the period of deposition of the Högklint Beds on Gotland. 1 -shale and mudstone; 2 - marlstones; 3 -bedded limestones; 4 -reefs of the present Högklint outcrop area. The dotted line is the boundary of the preserved subsurface and submarine Wenlock deposits of the Russian Platform, including the outcrop areas; the dashed line at bottom left marks the approximate boundary between the epicontinental sea of the Russian Platform and the Wendean Basin.

The exposed Högklint reefs and mounds form a linear belt that has been compared by some authors with a barrier complex, but the presence of Philip structures (Fig. 4) outside the present coast shows that the original spatial distribution was more widespread. There is no direct evidence of a Högklint shoreline, but the general NE-SW orientation of ripple marks at different horizons suggests an alignment close to this trend, and the evidence of local emergence at the end of Högklint times suggests that the shore was no great distance to the north of the reef area.

Similar trends from sedimentary structures throughout the sequence suggest that the shoreline maintained a generally similar NE-SW trend and that it too migrated south-eastward in a fairly constant position relative to the carbonate belts. In some units (for example, the Klinteberg and Eke Beds), intertidal limestones are preserved to the north and NE of the reef tracts to confirm the inshore shallowing in those directions.

The influx of siliciclastic sediments at two main horizons (Slite Siltstone and Burgsvik Beds) in western areas of Gotland gives the first signs of accelerated sediment supply from nearby areas to the west and NW, probably in part as a response to tectonic activity in the growing Caledonide mountain chain still further to the west. The Burgsvik Beds include beach and foreshore deposits that can be regarded as precursors of Old Red Sandstone facies in this part of the Baltic.

Tectonic movements immediately to the west of Gotland were also responsible for triggering the deformation of plastic sediments in parts of the Slite and Burgsvik Beds (Figs. 5, 7). By the end of Ludlow times, the shoreline lay close to the southern margin of Gotland, with the calcareous belts entirely to the south in the present Baltic; by the end of Silurian times, the regression was complete as the continuing Caledonian orogeny led to the spread of Old Red Sandstone continental facies across the whole of Balto-Scandia.

EPISODES, Vol. 1981, No. 2.

\section{Postscript}

Visiting geologists will find much more to attract them to Gotland in addition to the history of a Silurian regression, as the Quaternary geology and landforms are equally spectacular in places (Fig. 10). Further attractions include a unique flora, in which the orchids take pride of place, together with a wealth of archaeology and art in more than 3000 cairns, Bronze Age ship burials, picture stones, and almost 100 Medieval churches. The capital town of Visby with its virtually complete early Medieval town wall is the best preserved town of the former Hanseatic League.

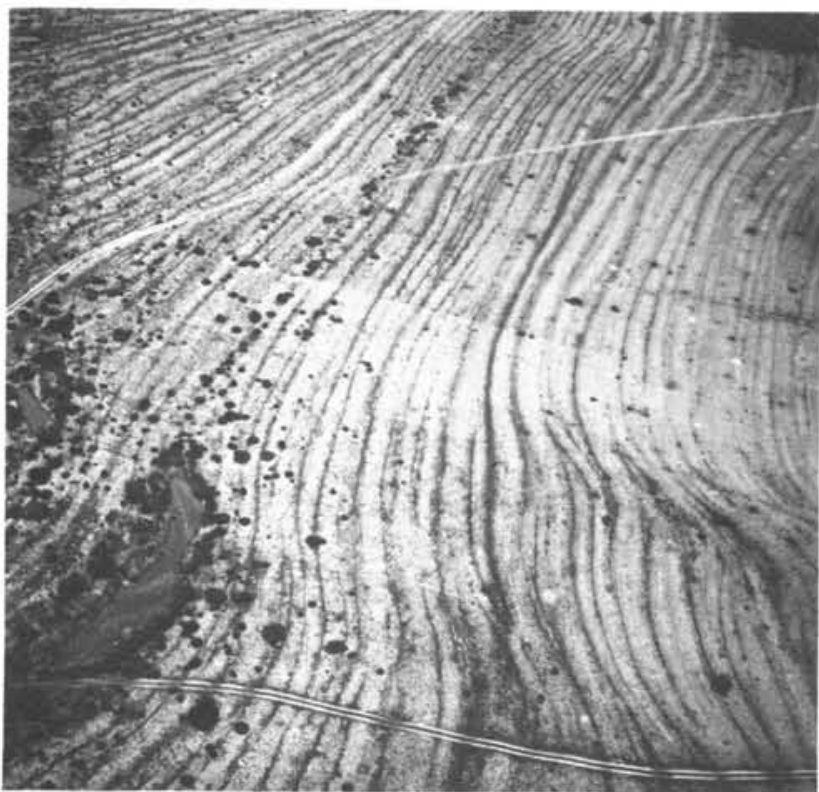

Figure 10. Aerial view of raised Quaternary beach ridges at Barshaga, southernmost tip of Gotland; these features were noticed by Linnaeus on his tour in 1741. (Photo courtesy A. Philip)

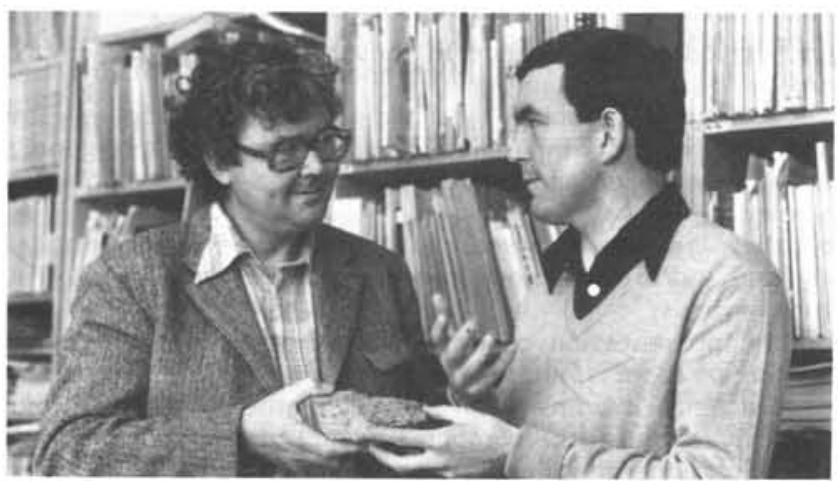

ABOUT THE AUTHORS:

Dr. Sven Laufeld (left) is a First State Geologist and Head of the Museum Department, Geological Survey of Sweden. He is a graduate and Docent of the University of Lund, where he previously taught geology and palaeontology; he has also taught at the University of Alaska in Fairbanks. Dr. Laufeld is Leader of the Swedish Working Group for Project Ecostratigraphy, and has research interests centred mainly on Chitinozoa and Lower Palaeozoic biostratigraphy, particularly on Gotland.

Dr. Michael G. Bassett (right) is Head of the Department of Geology, National Museum of Wales (U.K.), currently on leave at Naturhistoriska Riksmuseet, Stockholm, Sweden. He is Secretary-General of the International (IUGS) Commission on Stratigraphy, with research interests in Palaeozoic Brachiopoda and biostratigraphy. A graduate of the University of Wales and a Research Associate of the Department of Palaeobiology, University of Uppsala, Dr. Bassett has worked extensively on Gotland and in other areas of Scandinavia. 